\title{
PERAN PEMETAAN POTENSI PEMANFAATAN RUANG BERBASIS SISTEM INFORMASI GEOGRAFIS DALAM PENYELENGGARAAN PELAYANAN PUBLIK KELURAHAN (STUDI KASUS: KELURAHAN SONDAKAN, KECAMATAN LAWEYAN, KOTA SURAKARTA)
}

Rufia Andisetyana Putri ${ }^{1}$, Murtanti Jani Rahayu ${ }^{1}$, Erma Fitria Rini ${ }^{1}$, Winny Astuti ${ }^{1}$, Hakimatul Mukaromah ${ }^{1}$, Paramita Rahayu $^{1}$ dan Isti Andini ${ }^{1}$

${ }^{1}$ Program Studi Perencanaan Wilayah dan Kota, Fakultas Teknik, Universitas Sebelas Maret

\begin{abstract}
Abstrak
Tampilan digital data pemanfaatan ruang berbasis sistem informasi geografis (SIG) memungkinkan peningkatan efisiensi proses penyimpanan, pembaharuan, dan akses ulang data. Hal ini mendukung optimalisasi tugas aparat kelurahan dalam menyelenggarakan pelayanan publik. Tujuan artikel ini adalah menemukenali peran pemetaan potensi pemanfaatan ruang kelurahan berbasis SIG dalam penyelenggaraan pelayanan publik kelurahan. Tujuan ini dicapai melalui 2 tahapan, yakni (1) pemetaan potensi pemanfaatan ruang kelurahan berbasis sistem informasi geografis, dan (2) analisis peran pemetaan potensi pemanfaatan ruang kelurahan berbasis SIG dalam penyelenggaraan pelayanan publik kelurahan. Metode penelitian adalah studi kasus, dengan teknik analisis spasial menggunakan software ArcGIS, serta teknik deskriptif. Hasil analisis menunjukkan bahwa peta pemanfaatan ruang berbasis SIG memuat informasi spasial berupa lokasi, sebaran dan luasan tiap fungsi bangunan berperan dalam mendukung penyelenggaraan pelayanan publik aparat Kelurahan Sondakan, baik pada bidang pemerintahan, pembangunan dan ketentraman ketertiban, dan pemberdayaan masyarakat.
\end{abstract}

Kata kunci: kelurahan; pelayanan publik; pemanfaatan ruang; pemetaan; sistem informasi geografis

\begin{abstract}
The digital display of spatial-use data based on geographic information systems (GIS) makes the process of storing, updating, and adding data much more efficient and accessible. This supports the optimization of the duties of the sub-district staff in providing public services. The purpose of this article is to identify the role of spatial-use potential mapping based on GIS in the implementation of subdistrict public services. This goal is achieved through 2 stages, namely (1) mapping the potential use of urban village space based on geographic information systems and (2) analyzing the role of spatial-use potential mapping based on GIS in the implementation of sub-district public services. The research method is case study, with spatial analysis technique using ArcGIS software and descriptive technique. The results of the analysis show that the GIS-based spatial use map contains spatial information in the form of location, distribution, and area of each building function plays a role in supporting the implementation of public services for the Sondakan subdistrict staff, both in the government section, development and peace of order section, and community empowerment section.
\end{abstract}

Keywords: geographic information system; mapping; public services; spatial use; sub-district

\section{PENDAHULUAN}

Upaya peningkatan efektivitas dan efisiensi pelayanan publik dapat dioptimalkan melalui dukungan teknologi informasi berbasis Sistem Informasi Geografis (SIG). Pada Tahun 1972, SIG mulai dioperasionalkan di Indonesia dengan nama Data Banks for Development untuk keperluan lingkungan pemerintahan dan militer (Aini, 2007). Selanjutnya, SIG mengalami perkembangan yang cukup pesat karena adanya dukungan sumberdaya pada lingkungan akademis.

Dokumen pelayanan dan digitasi data merupakan salah satu input utama dalam proses pengambilan keputusan dalam lingkup pelayanan publik (Aini, 2007). Ketersediaan data digital menjadi indikator penilaian kinerja publik yang dapat dinilai secara langsung oleh masyarakat. Efisiensi dan efektivitas penyimpanan, pembaharuan, dan akses data dapat ditingkatkan dengan adanya tampilan data digital (Budiyanto, 2002). Hal ini juga berlaku pada data potensi pemanfaatan 
ruang skala Kelurahan sebagai salah satu basis data penting dalam pengambilan keputusan yang menjadi kebijakan perkotaan.

Karakter perkotaan yang dinamis yang salah satunya ditandai oleh tingginya kecepatan perkembangan pemanfaatan ruang membutuhkan sistem basis data faktual yang mudah diperbarui dan mudah diakses. Kelurahan merupakan penyelenggara pelayanan publik perkotaan pada skala terkecil yang menjadi pintu masuk utama bagi pencatatan perubahan pemanfaatan ruang pada level mikro. Kelurahan memegang tupoksi pelayanan publlik terkait pengendalian pemanfaatan ruang, seperti pengawasan lingkungan, dokumen pendukung pajak, dan fungsi bangunan. Oleh sebab itu, ketersediaan data digital pemanfaatan ruangan yang faktual berbasis SIG merupakan pendukung pelayanan publik skala kelurahan yang esensial.

Instrumen pengendalian pemanfaatan ruang dengan konteks spasial yang detail dan adaptif merupakan hal penting yang harus dimiliki pemerintah untuk mengatasi kompleksitas permasalahan perkotaan sebagai akibat tingginya perkembangan pemanfaatan ruang. Ketidaktersediaan basis data yang efektif dan efisien sebagai pendukung instrumen pengendalian dapat memicu terjadinya bentuk-bentuk penyimpangan pemanfaatan ruang. Dalam hal ini, permasalahan terkait penyimpangan pemanfaatan ruang dapat lebih cepat dideteksi melalui ketersediaan dan kemudahan akses basis data yang mampu menampilkan data faktual pemanfaatan ruang, serta mengakomodasi kepentingan pembaharuan data.

Kelurahan Sondakan mempunyai luas 78,5 Ha dengan jumlah penduduk 12.259 pada tahun 2019 (Badan Pusat Statistik Kota Surakarta, 2020). Penggunaan lahan di kelurahan didominasi oleh pemukiman, seperti pada umumnya kelurahan di kota-kota. Lokasi Kelurahan Sondakan memiliki nilai strategis pada pusat Kota Surakarta, dengan potensi pengembangan aktivitas perdagangan dan jasa. Kelurahan Sondakan berada dekat dengan Stasiun Purwosari, kawasan perdagangan dan industri batik di samping beberapa perkantoran besar. Kegiatan industri batik yang menjadi icon utama di Kecamatan Laweyan berasal dari kelurahan ini. Dalam hal ini, tingginya peluang perubahan pemanfaatan ruang yang memicu konflik kepentingan antar aktivas dapat disebabkan oleh kompleksitas potensi kawasan. Ketidakteresediaan basis data geografis yang aplikatif juga turut andil memicu terjadinya konflik spasial dan tidak terkendalinya dinamika pemanfaatan ruang perkotaan. Peta pemanfaatan ruang tiap persil bangunan di Kelurahan Sondakan dapat dilihat pada Gambar 7.

Dalam menjalankan fungsi pelayanan publik, Kelurahan Sondakan dipimpin oleh seorang Lurah. Lurah dibantu oleh Sekretaris dan tiga Kepala Seksi yang sekaligus menjadi ruang lingkup tugas pelayanan kelurahan, yakni Pemerintahan dan Ketentraman Ketertiban, Pembangunan dan Lingkungan Hidup, serta Pemberdayaan Masyarakat (Pemerintah Kota Surakarta, 2016). Ketersediaan data spasial berbasis SIG dengan pembaharuan yang bersifat dinamis dapat menjadi perangkat dalam inventarisasi dan monitoring perubahan penggunaan tanah dan bangunan, dan selanjutnya memungkinkan percepatan proses menemukenali permasalahan di lapangan agar dapat segera ditangani secara optimal (Asnawati \& Kusuma, 2011; Muliantara, 2009).

Berdasarkan penelitian-penelitian sebelumnya, SIG memiliki peran penting untuk mendukung peningkatan efisiensi pelayanan publik dalam lingkup perencanaan wilayah dan kota. SIG dapat dimanfaatkan sebagai basis data infrastruktur perkotaan, seperti sistem pengelolaan sampah, pengelolaan sungai dan air tanah, bahkan permodelan perawatan jaringan jalan (Adeyeye, lkpokonte, \& Arabi, 2019; Cecílio, Chiquieri, Freitas, \& Gonçalves, 2019; Singh, 2019). Dalam pengelolaan penggunaan lahan perkotaan, SIG dapat berperan dalam penilaian area perkotaan layak huni, maupun menampilkan perubahan tutupan lahan secara detail dan akurat (Bo, Danlin, \& Yaojun, 2019; Chowdhury, Hasan, \& Abdullah-Al-Mamun 2020). Selain itu, SIG juga dapat menjadi alat bantu untuk menemukenali keterkaitan antara aktivitas manusia dan lingkungannya (Chowdhury et al., 2020). Besarnya manfaat SIG terkait dalam efisiensi pelayanan publik diatas mendorong peneliti untuk menemukenali peran pemetaan potensi pemanfaatan ruang kelurahan berbasis SIG dalam penyelenggaraan pelayanan publik pada skala kelurahan.

\section{METODE}

Penelitian ini menggunakan metode studi kasus, yakni pendekatan suatu kasus secara detail dengan menggunakan data kuantitatif dan/atau kualitatif (Yin, 2014). Adapun teknik analisis yang digunakan dalam tiap tahapan penelitian, sebagai berikut.

a) Pemetaan potensi pemanfaatan ruang Kelurahan Sondakan berbasis sistem informasi geografis (SIG) 
Pemetaan potensi pemanfaatan ruang di Kelurahan Sondakan berbasis sistem informasi geografis dilakukan berdasarkan survey dari data primer dengan metode tracking dan marking. Hasil pengumpulan data digunakan sebagai input utama dalam pembangunan sistem informasi dengan menggunakan perangkat lunak ArcGIS 10.3. Output berupa potensi kelurahan yang diwujudkan dalam bentuk peta sebaran sarana pelayanan dan peta fungsi bangunan Kelurahan Sondakan.

b) Analisis peran pemetaan potensi pemanfaatan ruang kelurahan berbasis SIG dalam penyelenggaraan pelayanan publik kelurahan.

Analisis yang digunakan adalah deskriptif dengan input data berupa ruang lingkup tugas perangkat Kelurahan Sondakan, meliputi Seksi Pemerintahan dan Ketentraman Ketertiban, Seksi Pembangunan dan Lingkungan Hidup, serta Seksi Pemberdayaan Masyarakat. Ruang lingkup tugas dari tiap seksi di kelurahan menggunakan hasil analisis pada tahap sebelumnya. Output berupa peran pemetaan potensi pemanfaatan ruang kelurahan berbasis SIG dalam penyelenggaraan pelayanan publik kelurahan.

\section{HASIL DAN PEMBAHASAN}

\subsection{PEMETAAN POTENSI PEMANFAATAN RUANG KELURAHAN SONDAKAN BERBASIS SISTEM INFORMASI GEOGRAFIS (SIG)}

\subsubsection{Pemetaan Potensi Sarana Pelayanan Umum}

Ditinjau dari fungsinya, sarana dapat diklasifikasikan menjadi sarana pendidikan, sarana kesehatan, sarana perdagangan, sarana peribadataan, sarana kebudayaan dan rekreasi, dan ruang terbuka hijau. Kelurahan Sondakan memiliki 7 sarana pendidikan yang tersebar di seluruh wilayah. Tujuh sarana pendidikan, meliputi 5 sekolah dasar dan 2 perguruan tinggi. Berdasarkan informasi dalam Gambar 1, lima Sekolah Dasar berada di RW II, RW IV, RW V, RW VIII, RW XII, dengan radius pelayanan menjangkau seluruh wilayah Kelurahan Sondakan, bahkan hingga kelurahan di sekitarnya dengan luasan buffer area $4,77 \mathrm{Km}^{2}$. Adapun sarana pendidikan Perguruan Tinggi berada di RW XV dan RW IV (Gambar 1).

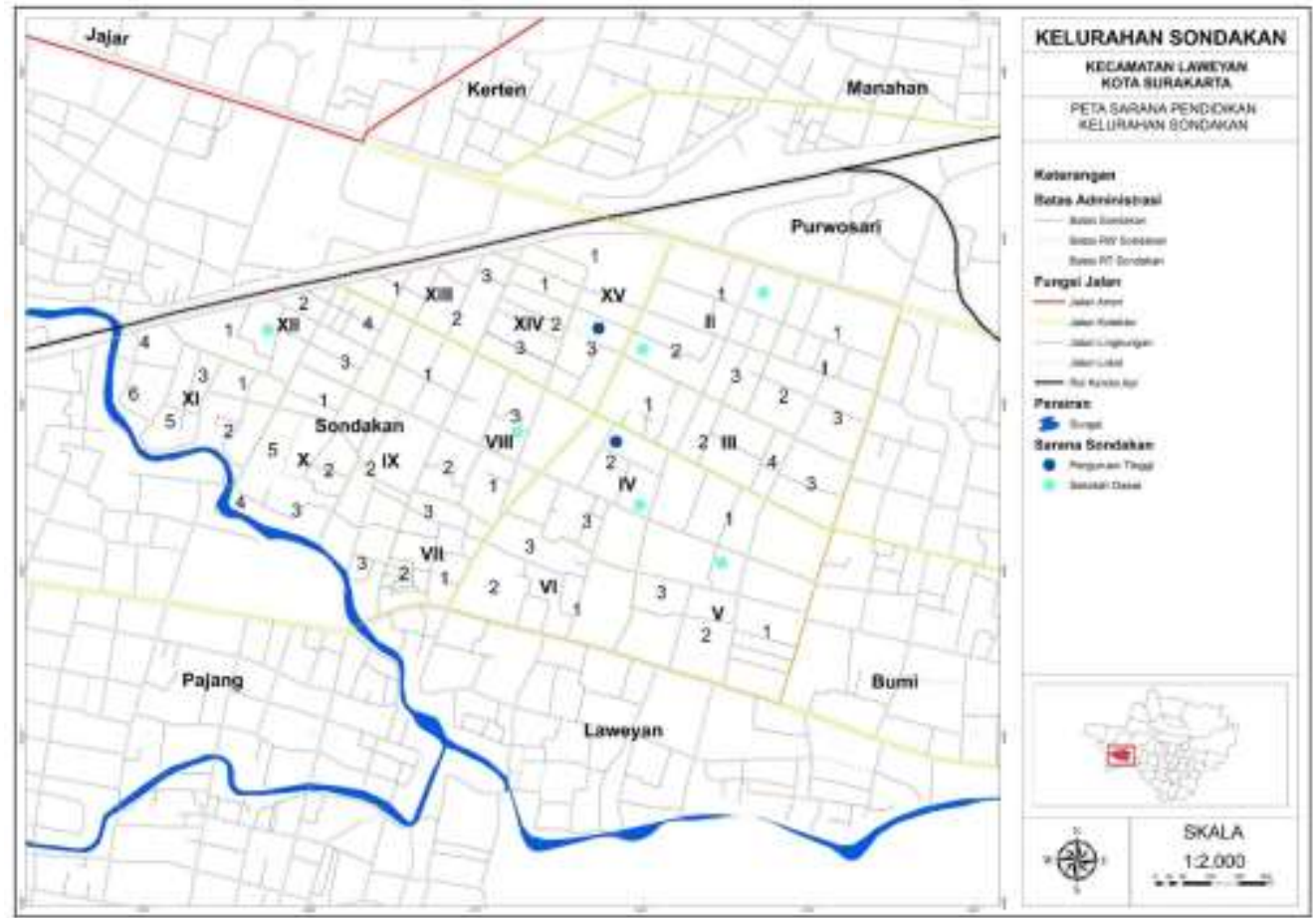




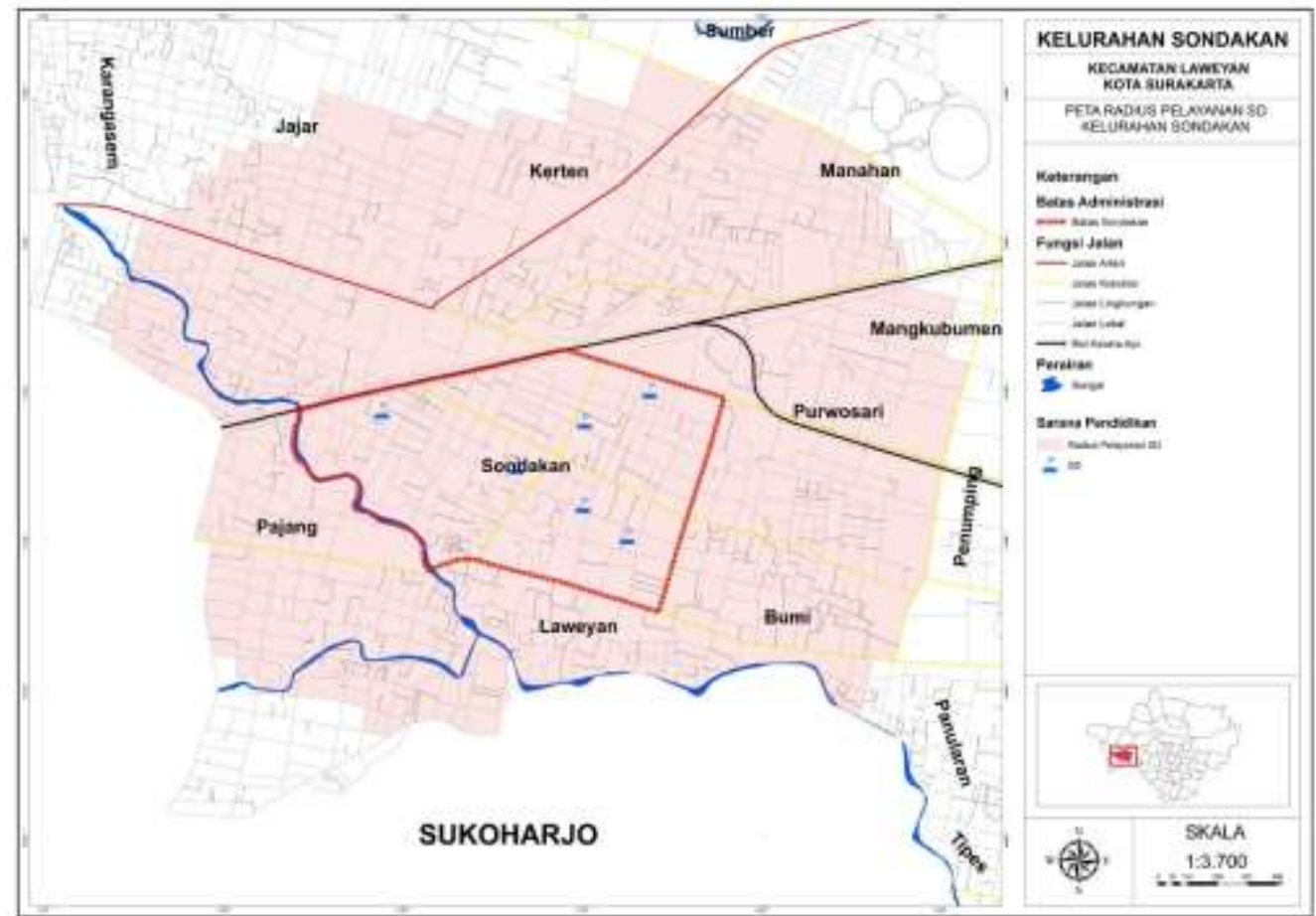

Gambar 1. Peta Sebaran dan Radius Pelayanan Sarana Pendidikan di Kelurahan Sondakan

Sarana kesehatan yang dimiliki oleh Kelurahan Sondakan adalah satu Puskesmas Pembantu. Puskesmas Pembantu terletak di RW VII (Gambar 2). Puskemas Pembantu ini memiliki jangkauan pelayanan ke seluruh Kelurahan Sondakan, bahkan melayani wilayah di sekitarnya yang berbatasan langsung dengan Kelurahan Sondakan.

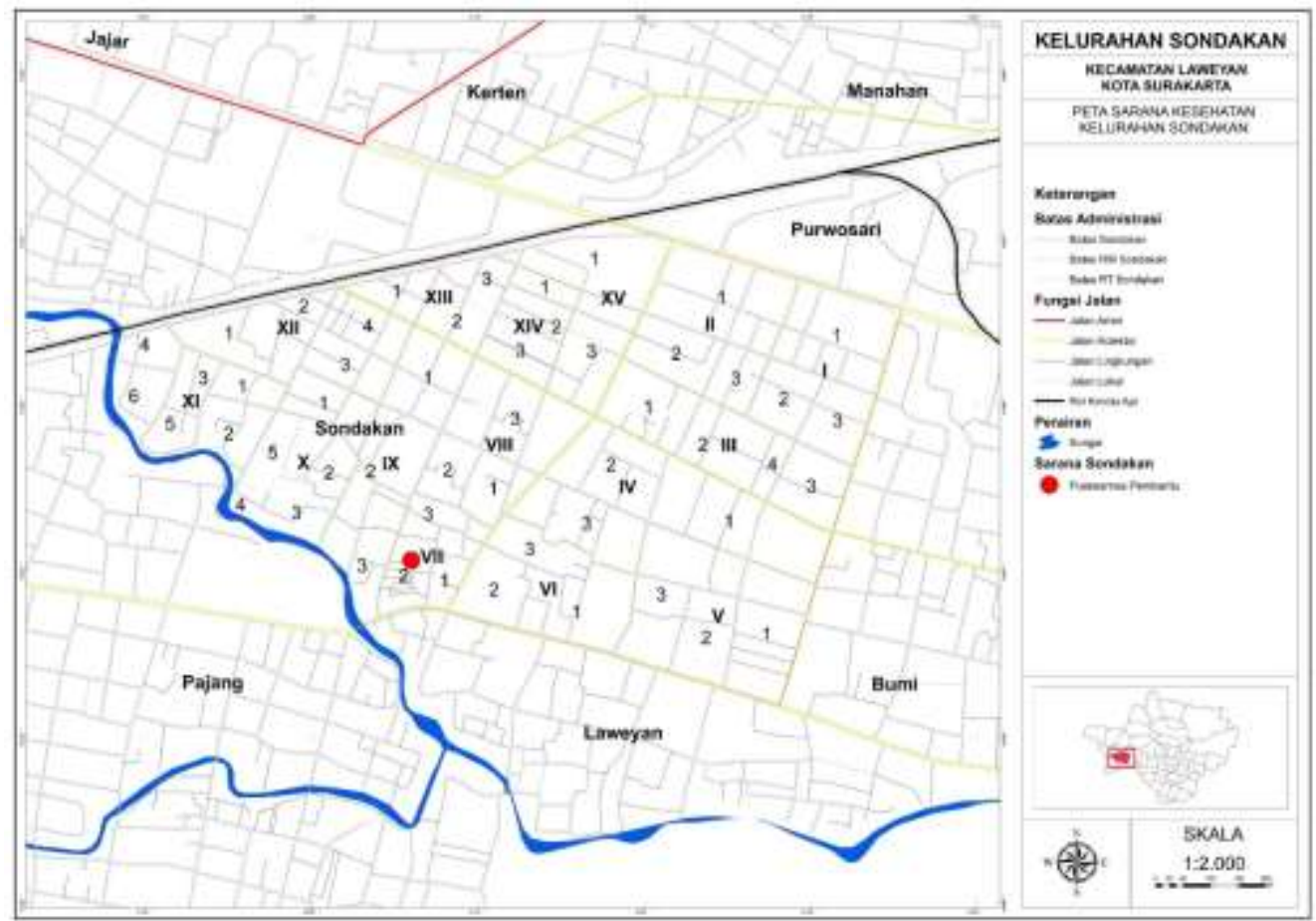




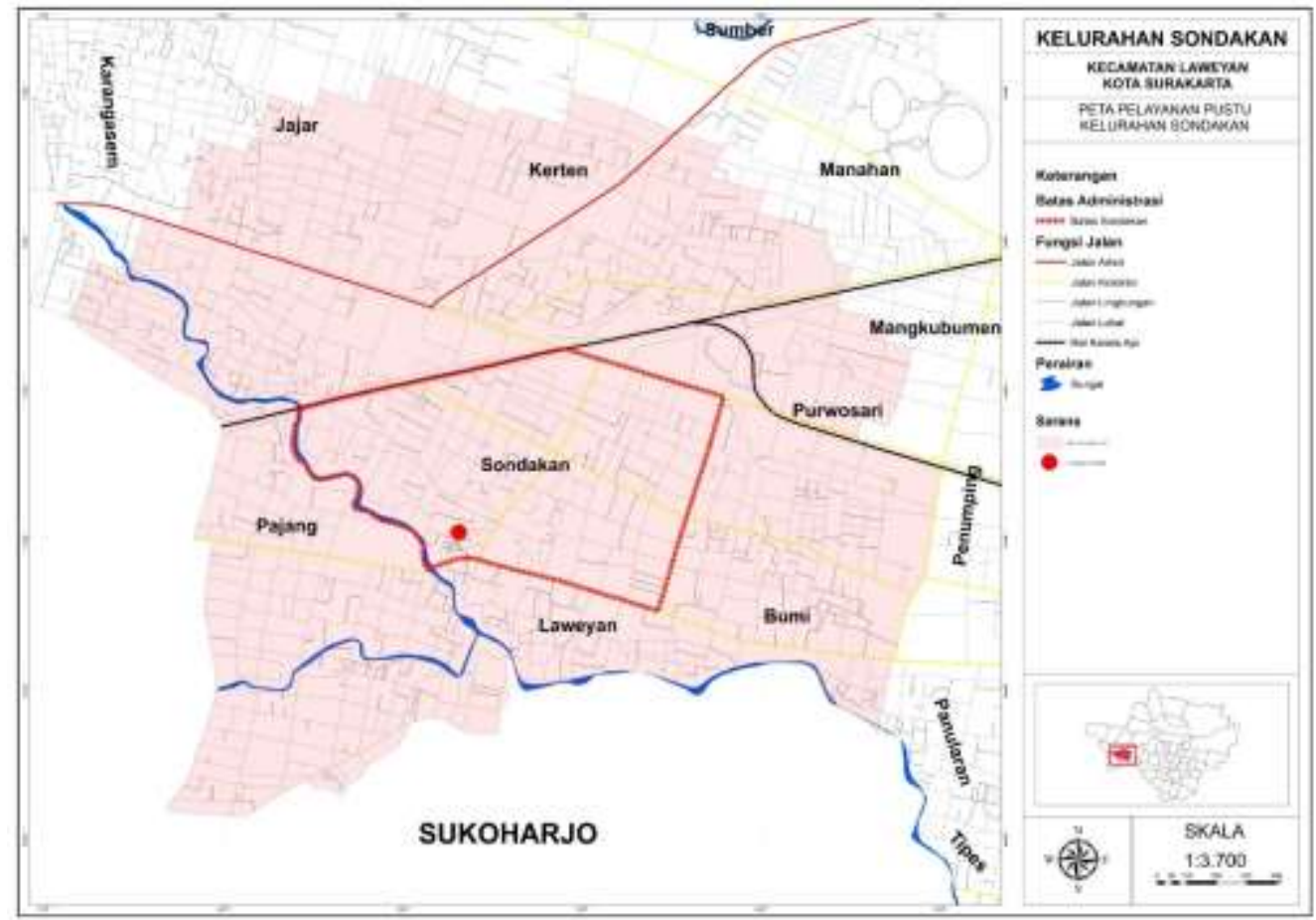

Gambar 2. Peta Sebaran dan Radius Pelayanan Sarana Kesehatan di Kelurahan Sondakan

Sarana perdagangan skala kelurahan yang dimiliki oleh Kelurahan Sondakan adalah pasar tradisional. Kelurahan Sondakan dilayani oleh 1 pasar tradisional yang terletak di RW XV (Gambar 3). Adapun sarana peribadatan, Kelurahan Sondakan memiliki 4 masjid yang berada di RW II, RW III, RW VI, dan RW XII (Gambar 4), dengan radius pelayanan $4,94 \mathrm{Km}^{2}$ hinga menjangkau kelurahan di sekitar Kelurahan Sondakan. Kelurahan Sondakan tidak memiliki sarana peribadatan untuk pemeluk agama selain Islam, namun kebutuhan pelayanannya sudah terpenuhi oleh sarana peribadatan di sekitar Kelurahan Sondakan.

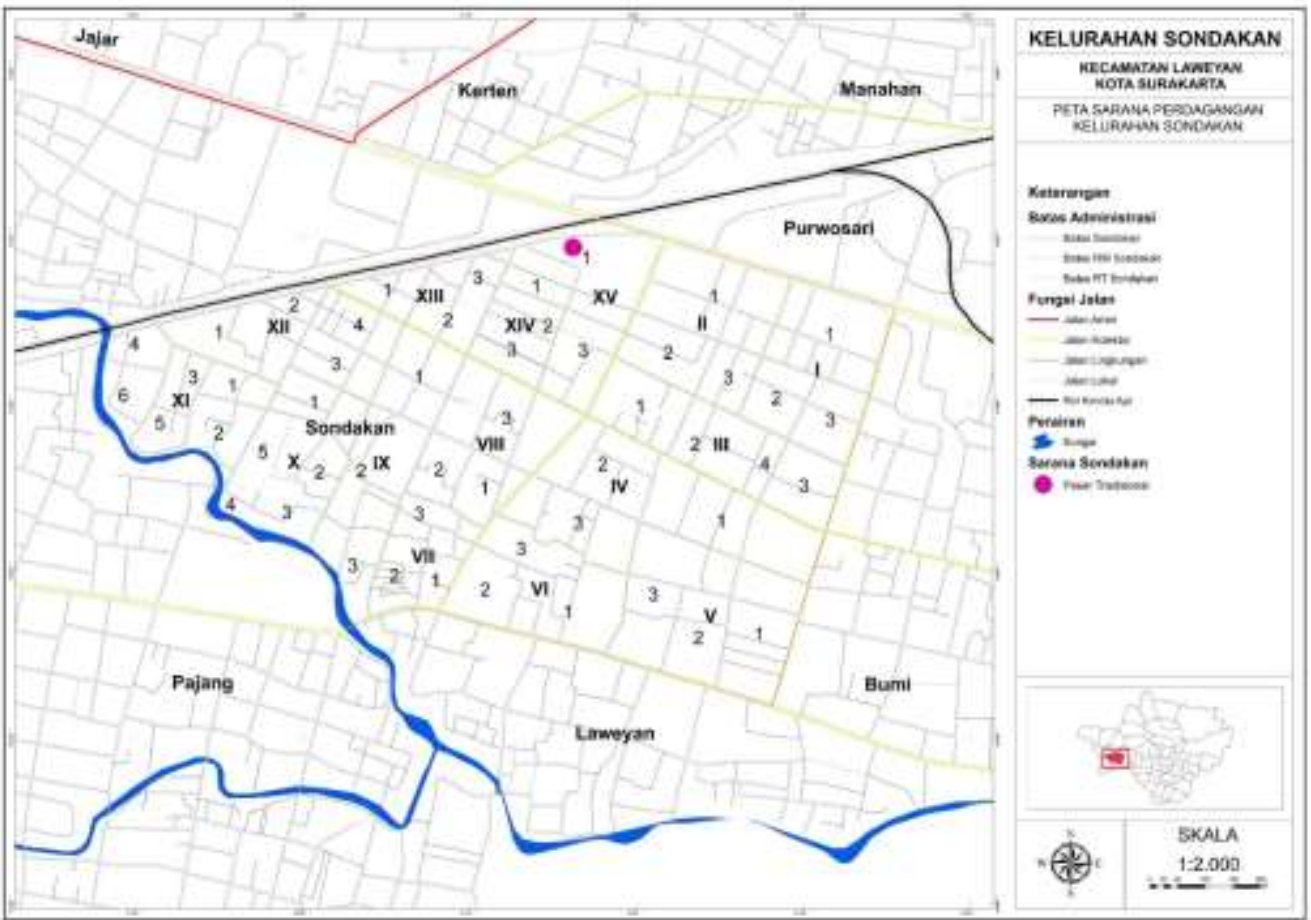

Gambar 3. Peta Sebaran Sarana Perdagangan di Kelurahan Sondakan 

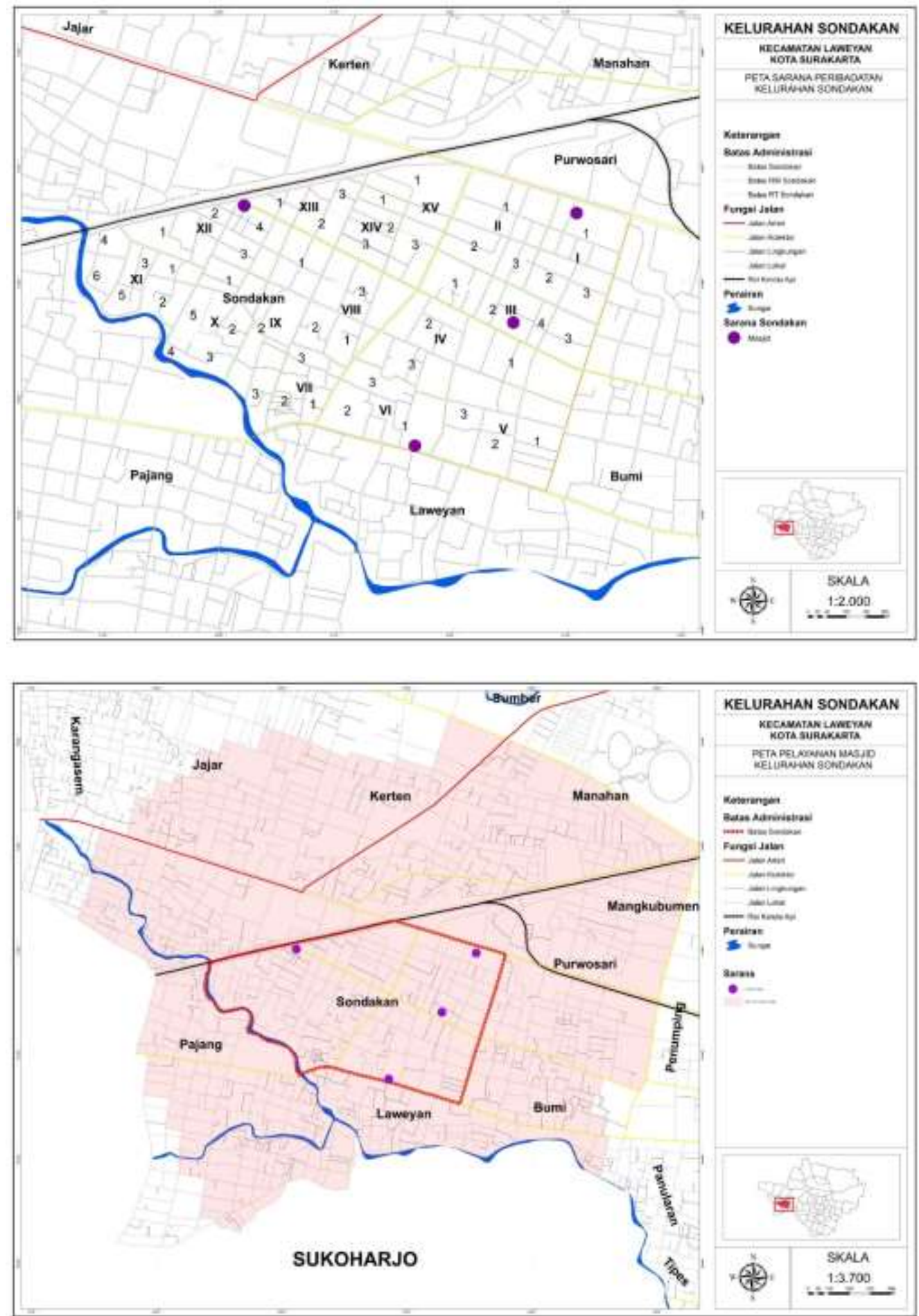

Gambar 4. Peta Sebaran dan Radius Pelayanan Sarana Peribadatan di Kelurahan Sondakan

Sarana kebudayaan dan rekreasi di Kelurahan Sondakan dapat dikelompokkan menjadi 2, yakni cagar budaya dan ruang serba guna. Kelurahan Sondakan memiliki 3 cagar budaya yang berlokasi di RW III dan RW XV, sedangkan ruang serba guna berada di RW XV (Gambar 5). Akan tetapi, jangkauan pelayanan ruang serba guna tidak menjangkau seluruh Kelurahan Sondakan, hanya seluas $0,13 \mathrm{Km}^{2}$. Ketidakmerataan jangkauan pelayanan ruang serbaguna sebagai sarana pertemuan warga dapat menjadi suatu permasalahan, sehingga perlu menjadi pertimbangan penting untuk mengoptimalkan pelayanan publik skala kelurahan.

Sarana ruang terbuka hijau di Kelurahan Sondakan dapat diklasifikasikan menjadi tiga, yakni makam, taman, dan lapangan. Kelurahan Sondakan memiliki 1 lapangan olahraga yang terletak di RW IX. Terdapat 2 unit taman yang berada di RW I dan RW II. Lapangan olahraga dan taman memiliki radius pelayanan yang menjangkau hingga kelurahan yang 
berbatasan langsung dengan Kelurahan Sondakan, atau seluas 4,41 $\mathrm{Km}^{2}$. Adapun makam sejumlah 5 unit yang berada di RW IV, RW VI, RW VII, RW X, dan RW XI (Gambar 6).

Berdasarkan paparan di atas, ditinjau dari sebaran pemanfaatan ruang berupa sarana publik, Kelurahan Sondakan memiliki potensi kelengkapan sarana yang dapat menjadi kekuatan bagi kelurahan untuk menyelenggarakan pelayanan publik masyarakat, terkecuali adanya isu kurangnya sarana gedung pertemuan.
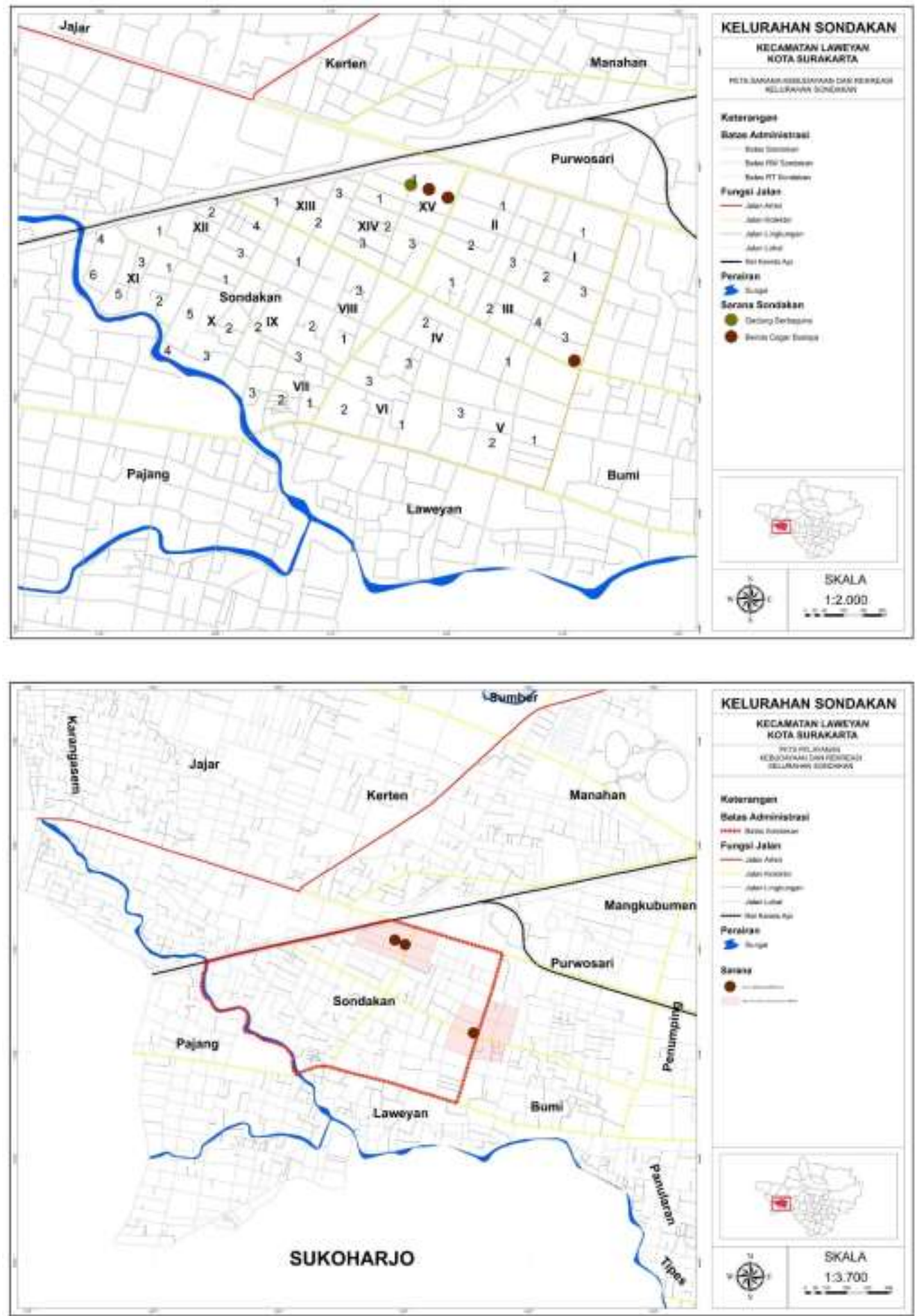
Gambar 5. Peta Sebaran dan Radius Pelayanan Sarana Kebudaayan dan Rekreasi di Kelurahan Sondakan
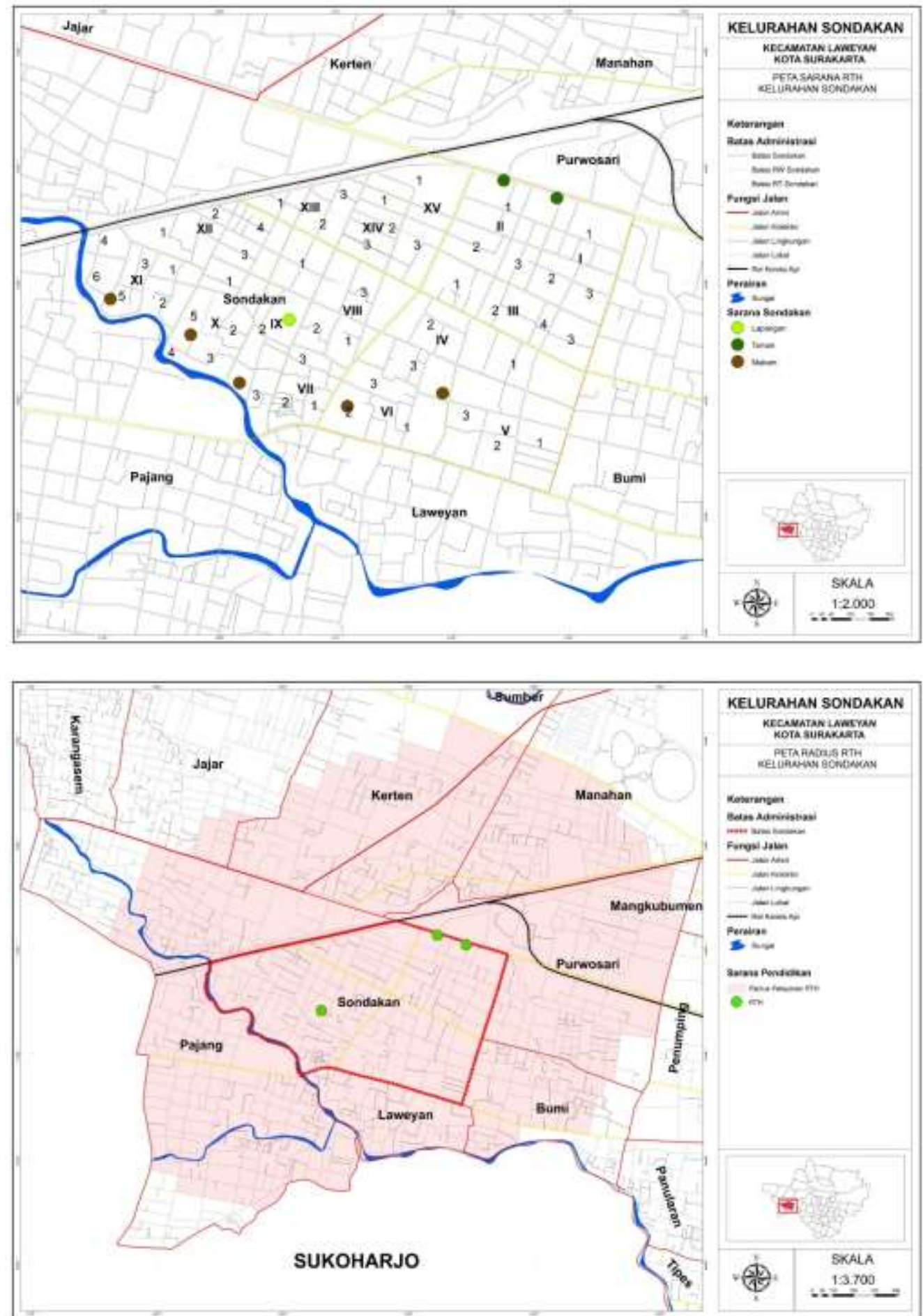

Gambar 6. Peta Sebaran dan Radius Pelayanan Sarana Ruang Terbuka Hijau di Kelurahan Sondakan

\subsubsection{Pemetaan Potensi Sebaran Fungsi Bangunan}

Fungsi bangunan di Kelurahan Sondakan didominasi oleh permukiman. Selain itu, lokasi yang berada dekat dengan pusat Kota Surakarta, menjadikan Kelurahan Sondakan sebagai wilayah dan strategis untuk pengembangan aktivitas perdagangan pada sepanjang jalan kolektor. Adapun fungsi bangunan pendukung yang lain adalah pendidikan, kesehatan, 
perkantoran, ruang terbuka hijau, dan sosial budaya yang seluruhnya mendukung kebutuhan penduduk dengan lokasi yang bercampur dengan kawasan permukiman (Gambar 7).

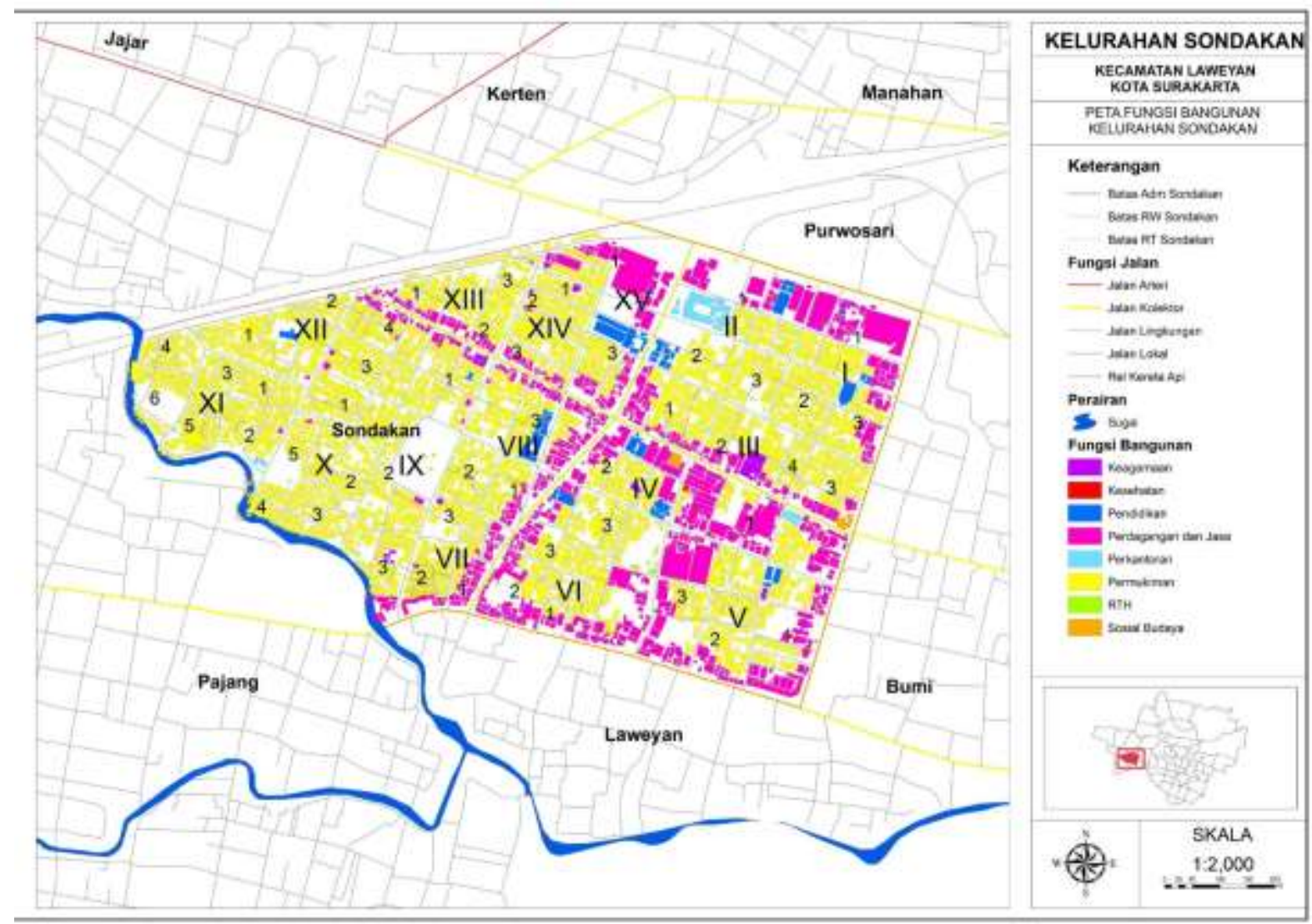

Gambar 7. Peta Fungsi Bangunan di Kelurahan Sondakan

\subsection{PERAN PETA POTENSI PEMANFAATAN RUANG BERBASIS SIG TERHADAP PENYELENGGARAAN PELAYANAN PUBLIK SKALA KELURAHAN}

Struktur organisasi dan tugas aparatur Kelurahan Sondakan, Kecamatan Laweyan, Kota Surakarta diatur dalam Peraturan Walikota Surakarta Nomor 27-C Tahun 2016 tentang Kedudukan, Susunan Organisasi, Tugas, Fungsi, dan Tata Kerja Perangkat Daerah Kota Surakarta. Lurah mempunyai tugas pokok menyelenggarakan sebagian kewenangan pemerintahan, pembangunan dan kemasyarakatan serta melaksanakan urusan pemerintahan yang dilimpahkan oleh Walikota. Dalam pelaksanaan tugas pokoknya, lurah dibantu oleh Sekretaris dan tiga Kepala Seksi, yakni Pemerintahan dan Ketentraman Ketertiban, Pembangunan dan Lingkungan Hidup, serta Pemberdayaan Masyarakat. Sekretaris bertugas untuk melaksanakan penyiapan perumusan kebijakan teknis, pembinaan, pengkoordinasian penyelenggaraan tugas secara terpadu, pelayanan administrasi dan pelaksanaan di bidang perencanaan, evaluasi dan pelaporan, keuangan, umum dan kepegawaian. Kepala Seksi Tata Pemerintahan mempunyai tugas melakukan penyiapan perumusan kebijakan teknis, pembinaan dan pelaksanaan di bidang tata pemerintahan, meliputi pelaksanaan urusan pemerintahan umum. Kepala Seksi Pembangunan dan Lingkungan Hidup mempunyai tugas melakukan penyiapan perumusan kebijakan teknis, pembinaan dan pelaksanaan di bidang pembangunan dan lingkungan hidup, meliputi pelaksanaan program pembangunan dan pembinaan pelestarian lingkungan hidup. Kepala Seksi Pemberdayaan Masyarakat mempunyai tugas melakukan penyiapan perumusan kebijakan teknis, pembinaan dan pelaksanaan di bidang pemberdayaan masyarakat, meliputi pelaksanaan program pembinaan kesehatan, keluarga berencana, bantuan dan pelayanan sosial. Berdasarkan tugas pokok yang telah dijabarkan, dapat disimpulkan bahwa pelayanan publik yang diselenggarakan oleh Kelurahan Sondakan meliputi pemerintahan, pembangunan, dan kemasyarakatan. Susunan organisasi perangkat Kelurahan Sondakan pada tahun 2020 dapat dilihat pada Gambar 8, sedangkan penjabaran tugas perangkat Kelurahan Sondakan dalam penyelenggaraan pelayanan publik skala kelurahan dapat dilihat pada Tabel 1. 


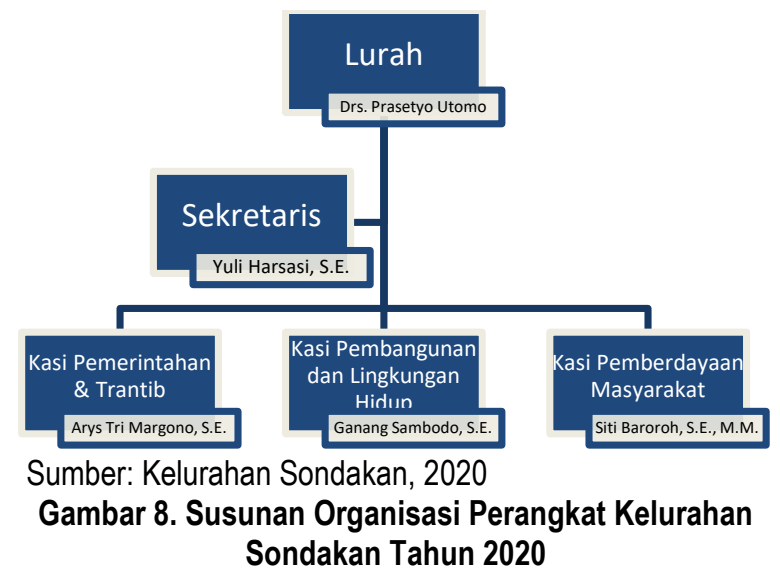

Tabel 1. Peran Peta Potensi Pemanfaatan Ruang Berbasis SIG terhadap Penyelenggaraan Pelayanan Publik Skala Kelurahan

\begin{tabular}{|c|c|c|}
\hline Bidang Pelayanan & $\begin{array}{c}\text { Tugas } \\
\end{array}$ & Peran Peta Berbasis SIG \\
\hline $\begin{array}{c}\text { Pemerintahan dan } \\
\text { Ketentraman } \\
\text { Ketertiban }\end{array}$ & $\begin{array}{l}\text { 1. Memfasilitasi pemungutan Pajak Bumi dan } \\
\text { Bangunan (PBB). }\end{array}$ & $\begin{array}{l}\text { Data spasial berbasis SIG berupa } \\
\text { persil tanah dan bangunan dapat } \\
\text { menjadi perangkat dalam penetapan } \\
\text { dan monitoring PBB }\end{array}$ \\
\hline $\begin{array}{l}\text { Pembangunan dan } \\
\text { Lingkungan Hidup }\end{array}$ & $\begin{array}{l}\text { 1. Pengelolaan data bidang pembangunan, } \\
\text { sarana prasarana umum, jalan dan } \\
\text { jembatan. } \\
\text { 2. Pengelolaan data usaha konservasi tanah, } \\
\text { lingkungan hidup, kebersihan dan keindahan } \\
\text { kota serta Ruang Terbuka Hijau (RTH). } \\
\text { 3. Fasilitasi pembinaan dan pemberian } \\
\text { bantuan terhadap usaha-usaha masyarakat } \\
\text { di bidang perekonomian, Usaha Mikro, Kecil } \\
\text { dan Menengah (UMKM), koperasi, } \\
\text { peternakan, pertanian dan usaha lainnya } \\
\text { yang diselenggarakan oleh instansi terkait. } \\
\text { 4. Pemantauan terhadap kelancaran } \\
\text { pengelolaan sampah. }\end{array}$ & $\begin{array}{l}\text { Data lokasi sarana dan jaringan } \\
\text { prasarana dapat menjadi dasar } \\
\text { penentuan jangkauan pelayanan } \\
\text { sarana prasarana, guna } \\
\text { menemukenali isu terkait } \\
\text { ketidakmerataan sarana prasarana. }\end{array}$ \\
\hline $\begin{array}{l}\text { Pemberdayaan } \\
\text { Masyarakat }\end{array}$ & $\begin{array}{l}\text { 1. Inventarisasi dan pengelolaan data keluarga } \\
\text { miskin, rumah tidak layak huni, korban } \\
\text { bencana alam dan penyandang masalah } \\
\text { kesejahteraan sosial lainnya. }\end{array}$ & $\begin{array}{l}\text { Data persil tanah dan bangunan } \\
\text { dapat menjadi instrumen dalam } \\
\text { memetakan lokasi keluarga miskin, } \\
\text { rumah tidak layak huni, korban } \\
\text { bencana alam dan penyandang } \\
\text { masalah kesejahteraan sosial } \\
\text { lainnya }\end{array}$ \\
\hline
\end{tabular}

Sumber: Pemerintah Kota Surakarta, 2016

Sistem informasi geografis memuat data berorientasi geografis berupa lokasi yang dilengkapi sistem koordinat tertentu. Aplikasi sistem informasi geografis dapat menunjukkan lokasi, kondisi, tren, pola dan pemodelan dari suatu karakteristik wilayah (Prahasta, 2002). Oleh sebab itu, akurasi data spasial yang ditunjukkan SIG dapat berperan dalam mendukung penyelengaaran pelayanan publik oleh tiap bidang aparat kelurahan.

Pada Bidang Pemerintahan, peta potensi pemanfaatan ruang berbasis SIG mendukung tugas aparat kelurahan dalam memfasilitasi pemungutan Pajak Bumi dan Bangunan (PBB). Hal ini sejalan dengan pendapat Muliantara (Muliantara, 2009), bahwa data spasial berbasis SIG dapat menjadi perangkat dalam penetapan dan monitoring PBB. Selain itu, ketersediaan data jaringan jalan yang relatif akurat, mempermudah aparat kelurahan mengenali lokasi objek pajak dan menentukan rute dalam kegiatan monitoring PBB, sehingga menghemat waktu petugas (Fahrudi \& Hadiman, 2005). PBB dikenakan atas hak kepemilikan atas objek pajak berupa tanah dan/atau bangunan. Besaran PBB beragam tergantung 
pada jenis penggunaan lahan, luas lahan, dan harga jual tanah. Pada tanah dengan bangunan di atasnya, besaran PBB juga dipengaruhi oleh luas, jenis penggunaan, jumlah lantai, serta fasilitas pendukung tambahan yang terdapat pada bangunan tersebut. Ketersediaan data luasan persil dan jenis bangunan pada peta potensi pemanfaatan ruang berbasis SIG disini adalah sebagai acuan untuk penetapan besaran PBB, dengan dilengkapi verifikasi data lapangan. Selain itu, kemudahan pembaharuan data peta terhadap perubahan kondisi di lapangan menjadikan peta berbasis SIG dapat menjadi instrumen monitoring dalam pemungutan PBB di Kelurahan Sondakan. Peta persil bangunan Kelurahan Sondakan dapat dilihat pada Gambar 7.

Pada Bidang Pembangunan dan Lingkungan Hidup, ketersediaan peta pemanfaatan ruang berbasis SIG mampu memberikan data akurat mengenai lokasi sarana pelayanan publik. Sejalan dengan pendapat Asnawati dan Kusuma (Asnawati \& Kusuma, 2011) yang menyebutkan bahwa peta sebaran fasilitas dapat mempermudah dalam proses inventarisasi dan memantau permasalahan terkait jumlah fasilitas publik. Data ini dapat menjadi acuan aparat dalam menentuan jangkauan pelayanan optimum yang masih mampu diwadahi oleh tiap jenis sarana, sehingga dapat ditemukenali isu terkait ketidakmerataan sarana. Data tersebut juga mempermudah aparat dalam melakukan verifikasi isu di lapangan, sehingga permasalahan pelayanan publik dengan urgensi penanganan tinggi dapat diangkat dalam musrenbangkel dan menjadi dasar penyusunan kebijakan Kota Surakarta ke depannya. Peta sebaran dan radius pelayanan tiap jenis sarana pelayanan publik di Kelurahan Sondakan dapat dilihat pada Gambar 1, 2, 3, 4, 5, dan 6 .

Selanjutnya, pada bidang pemberdayaan masyarakat, ketersediaan peta persil bangunan dapat menjadi pegangan aparat kelurahan dalam proses survey inventarisasi lokasi keluarga miskin, rumah tidak layak huni, korban bencana alam dan penyandang masalah kesejahteraan sosial lainnya. Sejalan dengan pendapat Lasena dan Tambayong (2016) yang menyatakan bahwa sistem informasi geografis dapat bermanfaat untuk mengoptimalkan proses pendataan dan pelaksanaan program bantuan rumah layak huni secara tepat sasaran. Data lokasi yang relatif akurat dapat membantu aparat kelurahan dalam melakukan survey inventarisasi. Selain itu, aparat kelurahan juga dapat melakukan pembaharuan data SIG dengan memasukkan informasi terkait sebaran isu kesejahteraan sosial di Kelurahan Sondakan. Ketersediaan data lokasi yang akurat terkait permasalahan kesejahteraan sosial dapat membantu aparat kelurahan dalam menetapkan prioritas dalam menjalankan program pengendalian secara tepat sasaran.

\section{KESIMPULAN}

Peta pemanfaatan ruang berbasis SIG Kelurahan Sondakan memuat informasi spasial berupa lokasi, sebaran dan luasan tiap fungsi bangunan yang mendukung penyelenggaraan pelayanan publik oleh seluruh bidang dalam struktur organisasi kelurahan. Pada Bidang Pemerintahan, SIG berperan mendukung proses inventarisasi dan monitoring data terkait PBB. Peran dalam bidang pembangunan dan lingkungan hidup ditunjukkan oleh kemampuan SIG menjadi basis data yang menunjukkan lokasi, distribusi, jangkauan pelayanan, dan isu-isu terkait sarana pelayanan permukiman. Ketersediaan informasi ini penting agar dapat ditindaklanjuti oleh kebijakan agar pelayanan permukiman dapat berfungsi optimal dan merata. Adapun selanjutnya peran dalam Bidang Pemberdayaan Masyarakat ditunjukkan sebagai basis data untuk inventarisasi lokasi keluarga miskin, rumah tidak layak huni, korban bencana alam dan penyandang masalah kesejahteraan sosial lainnya. Hal ini dapat mempermudah aparat kelurahan dalam menetapkan prioritas dalam menjalankan program pengendalian secara tepat sasaran.

\section{DAFTAR PUSTAKA}

Adeyeye, O. A., Ikpokonte, E. A., \& Arabi, S. A. (2019). GIS-Based Groundwater Potential Mapping within Dengi Area, North Central Nigeria. Egyptian Journal of Remote Sensing and Space Science, 22(2), 175-181. https://doi.org/10.1016/j.ejrs.2018.04.003

Aini, A. (2007). Sistem Informasi Geofrafis Pengertian dan Aplikasinya. Yogyakarta: STMIK AMIKOM.

Asnawati, \& Kusuma, G. P. (2011). Sistem Informasi Geografis (SIG) Fasilitas - Fasilitas Yang Ada di Kota Bengkulu Berbasis WEB. Jurnal Media Infotama, 7(2), 76-102.

Badan Pusat Statistik Kota Surakarta. (2020). Kecamatan Laweyan dalam Angka 2020. Surakarta: BPS Kota Surakarta.

Bo, F., Danlin, Y., \& Yaojun, Z. (2019). The Livable Urban Landscape: GIS and Remote Sensing Extracted Land Use Assessment For Urban Livability in Changchun Proper, China. Land Use Policy, 87(May). https://doi.org/10.1016/j.landusepol.2019.104048

Budiyanto, E. (2002). Sistem Informasi Geografis Menggunakan ArcView GIS. Yogyakarta: Andi.

Cecilio, I. da S., Chiquieri, J., Freitas, R. R. de, \& Gonçalves, W. (2019). Holistic analysis of the Vehicle Routing Problem: an approach for GIS-T. International Journal of Advanced Engineering Research and Science, 6(9), 116-131. https://doi.org/10.22161//JAERS.69.13 
Chowdhury, M., Hasan, M. E., \& Abdullah-Al-Mamun, M. M. (2020). Land Use/Land Cover Change Assessment of Halda Watershed Using Remote Sensing and GIS. Egyptian Journal of Remote Sensing and Space Science, 23(1), 63-75. https://doi.org/10.1016/j.ejrs.2018.11.003

Fahrudi, I., \& Hadiman. (2005). Pemanfaatan Sistem Informasi Geografis untuk Penentuan Jalur Optimum dalam Kegiatan Verifikasi Lapangan Pajak Bumi dan Bangunan : Studi kasus di Kota Malang. Universitas Gadjah Mada.

Kelurahan Sondakan. (2020). Struktur Organisasi Kelurahan Sondakan.

Lasena, M., \& Tambayong, D. (2016). Sistem Informasi Geografis Bantuan Rumah Layak Huni Berbasis Web Pada Dinas Sosial Kabupaten Bolaang Mongondow Utara,. Teknosains, 10(1), 89-103.

Muliantara, A. (2009). Sistem Informasi Geografis Dalam Penetapan Pajak Bumi dan Bangunan. Jurnal IImu Komputer, 2(1).

Pemerintah Kota Surakarta. (2016). Peraturan Walikota Surakarta Nomor 27-C Tahun 2016 Tentang Kedudukan, Susunan Organisasi, Tugas, Fungsi, dan Tata Kerja Perangkat Daerah Kota Surakarta.

Prahasta, E. (2002). Sistem Informasi Geografis Tutorial ArcView. Bandung: Informatika.

Singh, A. (2019). Remote sensing and GIS applications for municipal waste management. Journal of Environmental Management, 243, 22-29. https://doi.org/10.1016/J.JENVMAN.2019.05.017

Yin, R. K. (2014). Case Study Research Design and Methods (5th ed.). Thousand Oaks, California: Sage. 